\title{
PENGEMBANGAN MEDIA PEMBELAJARAN $Q R$ CARD AKUNTANSI UNTUK MENINGKATKAN MOTIVASI BELAJAR JURNAL PENUTUP SISWA KELAS XII IPS SMA NEGERI 2 BANTUL TAHUN PELAJARAN 2018/2019
}

\author{
DEVELOPING QR CARD ACCOUNTING LEARNING MEDIA TO IMPROVE \\ CLOSING ENTRIES LEARNING MOTIVATION OF XII IPS STUDENTS IN SMA \\ NEGERI 2 BANTUL IN ACADEMICS YEAR OF 2018/2019
}

\author{
Oleh: \\ Dahlia Fauziah \\ Pendidikan Akuntansi Universitas Negeri Yogyakarta \\ dahlia.fauziah18@gmail.com \\ Moh. Djazari \\ Staf Pengajar Jurusan Pendidikan Akuntansi Universitas Negeri Yogyakarta
}

\begin{abstract}
Abstrak
Penelitian ini bertujuan untuk mengembangkan Media Pembelajaran $Q R$ Card Akuntansi yang dapat mengingkatkan Motivasi Belajar Jurnal Penutup Siswa Kelas XII IPS SMA Negeri 2 Bantul. Penelitian ini merupakan penelitian pengembangan yang menggunakan model ADDIE. Penilaian kelayaan media dilakukan oleh ahli materi, ahli media, praktisi pembelajaran Akuntansi, dan siswa melalui uji coba kelompok kecil. Subjek penelitian ini adalah Siswa Kelas XII IPS SMA Negeri 2 Bantul dengan jumlah total 40 siswa. Pengumpulan data dilakukan dengan menggunakan kuisioner dan teknik analisis data menggunakan teknik analisis deskriptif kuantitatif. Hasil penelitian menunjukkan bahwa Media Pembelajaran QR Card Akuntansi layak digunakan sebagai media pembelajaran Akuntansi yang dapat meningkatkan Motivasi Belajar Jurnal Penutup meskipun relatif rendah. Hal ini dibuktikan dengan tingkat kelayakan Media Pembelajaran $Q R$ Card Akuntansi dinilai sangat layak oleh para ahli dan juga siswa dengan rata-rata skor 3,50 oleh ahli materi, 3,56 oleh ahli media, 3,60 oleh praktisi pembelajaran akuntansi, dan 3,34 oleh siswa. Kemudian dari perhitungan nilai gain diperoleh 0,17 yang termasuk kategori rendah dan hasil uji t berpasangan menunjukkan perbedaan yang signifikan antara sebelum dan sesudah menggunakan Media Pembelajaran $Q R$ Card Akuntansi.
\end{abstract}

Kata Kunci: Akuntansi, Belajar, Jurnal Penutup, Media, Motivasi, QR Card.

\section{Abstract}

This research aimed to develop QR Card Accounting Learning Media that could improve Closing Entries Learning Motivation of XII IPS students in SMA Negeri 2 Bantul. This research was a Research and Development study using ADDIE developmental model. Appropriateness of the media was assessed by content experts, media experts, accounting learning practitioners, and some students in a small scale try out. The subjects of the study were the students of XII IPS SMA Negeri 2 Bantul with the total number of 40 students. The data were collected using questionnaires, and the collected data were analyzed using descriptive quantitative. The results showed that QR Card Accounting Learning Media was suitable for use as a learning media that could improve the Closing Entries Learning Motivation even though the increase was relatively small The appropriateness of the media was further supported by all the expert and students evaluation. The media got the average score 3.50 from the content expert, 3.56 by the media expert, 3.60 by practitioners, and 3,34 by students. The 
gain score is 0.17 which is categorized as low, and the paired samples $t$ test results shows significant differences between before and after using QR Card Accounting Learning Media.

Keywords: Accounting, Closing Entries, Learning, Media, Motivation, QR Card.

\section{PENDAHULUAN}

Motivasi belajar adalah suatu dorongan yang berasal dari dalam diri siswa berupa kesediaan dan keinginan siswa untuk mencapai tujuan yang dikehendaki. Siswa dengan motivasi yang kuat akan memiliki banyak energi untuk melakukan kegiatan belajar. Motivasi Belajar Jurnal Penutup adalah dorongan yang berasal dari dalam siswa berupa kesediaan dan keinginan siswa untuk mencapai tujuan yaitu siswa dapat membuat Jurnal Penutup pada perusahaan jasa dengan benar. Adanya Motivasi Belajar Jurnal Penutup pada siswa yang tinggi tentu akan berpengaruh pula pada hasil belajar yang optimal.

Motivasi Belajar Jurnal Penutup pada siswa dapat mendorong siswa untuk melakukan suatu hal atau kegiatan. Kegiatan yang dilakukanpun akan terarah pada tujuan yang ingin dicapai siswa. Tidak sembarang melakukan kegiatan atau perbuatan tetapi siswa akan melakukan kegiatan-kegiatan yang sesuai untuk mencapai tujuannya yaitu menguasai kompetensi Jurnal Penutup pada perusahaan jasa, dan menyisihkan perbuatan yang tidak bermanfaat bagi tujuan tersebut.

Terdapat banyak faktor yang dapat mempengaruhi Motivasi Belajar Jurnal Penutup, diantaranya adalah motivasi intrinsik dan motivasi ekstrinsik. Motivasi intrinsik merupakan motivasi yang tidak perlu dirangsang dari luar, karena dorongan untuk melakukan suatu hal sudah ada dari dalam diri seseorang. Kebalikan dari motivasi intrinsik adalah motivasi ekstrinsik di mana motivasi tersebut memerlukan rangsangan dari luar untuk dapat tumbuh pada diri seseorang. Berbagai bentuk dan cara yang dapat menumbuhkan motivasi dalam kegiatan belajar di sekolah, diantaranya dengan memberikan hadiah, pujian, hukuman, adanya kompetisi, dan lain sebagainya. Di samping hal-hal yang telah disebutkan, ternyata menurut hasil penelitian yang dilakukan oleh Rodgers (2005) pemilihan media pembelajaran yang tepat yaitu media yang dapat mencuri perhatian siswa, dapat mempertahankan kepercayaan diri siswa, dan mempertahankan kepuasan dalam belajar berpengaruh pada peningkatan motivasi belajar siswa.

Media pembelajaran merupakan bagian yang tidak dapat terpisahkan dari proses pembelajaran. Kata media yang berasal dari bahasa Latin medius yang berarti tengah, dan pembelajaran yang berarti proses seseorang atau makhluk hidup untuk belajar. Maka, media pembelajaran adalah alat atau perantara dalam proses belajar. Adanya media pembelajaran sebagai alat bantu dalam proses belajar ini bertujuan untuk memudahkan dalam mencapai tujuan pembelajaran.

Perkembangan ilmu pengetahuan dan teknologi saat ini dapat mendorong upayaupaya pembaruan dalam pemanfaatan hasil-hasil teknologi dalam proses belajar. Para guru dituntut untuk bisa menggunakan alat-alat yang disediakan sekolah dan tidak menutup kemungkinan bahwa alat-alat tersebut sesuai dengan perkembangan zaman. Di samping mampu menggunakan alat-alat yang telah disediakan sekolah, guru juga dituntut untuk dapat megembangkan keterampilan membuat media pembelajaran yang akan digunakan apabila media tersebut belum tersedia.

Berkembangnya ilmu pengetahuan dan teknologi juga terjadi pada perusahaan retail yang menggunakan sistem pemeriksaan barang dengan teknologi kode batang (barcode). Kode batang (barcode) adalah suatu kumpulan data optik yang dibaca mesin (Yudhanto, 2011). Kode batang dengan bentuk garis dan spasi garis 
paralel dapat disebut kode batang atau simbologi linear atau 1D (1 dimensi). Kode batang dengan bentuk persegi, menggunakan titik, heksagon, dan bentuk geometri lainnya di dalam gambar disebut kode matriks atau simbologi $2 \mathrm{D} \quad(2$ dimensi). Kode batang 2 dimensi inilah yang saat ini lebih dikenal dengan Quick Response Code (QR Code).

$Q R \quad$ Code yang merupakan perkembangan dari barcode yang dapat memuat informasi dengan volume yang jauh lebih besar dibandingkan dengan barcode. QR Code adalah sebuah kode matriks dalam bentuk dua dimensi yang dikembangkan oleh perusahaan Jepang Denso-Wave pada tahun 1994 (Ridwan, 2010). QR Code ini bebas untuk dibuat/diproduksi, mudah diakses, dan dapat terbaca di sebagaian besar telepon pintar (Jackson, 2011). QR Code banyak digunakan di Jepang, sedangkan di Indonesia sendiri belum terlalu populer namun sudah mulai digunakan seperti pada beberapa artikel di harian Kompas untuk menyimpan URL. Meski belum terlalu populer, namun $Q R$ Reader untuk berbagai macam tipe telepon pintar sudah banyak tersedia di Play Store juga App Store untuk diunduh secara gratis.

Media Pembelajaran $Q R \quad$ Card Akuntansi merupakan media yang dimaksudkan sebagai pengembangan dari media pembelajaran kartu soal. Sama halnya dengan kartu soal yang berbentuk kartu dengan memuat soal di dalamnya, Media Pembelajaran $Q R$ Card Akuntasi juga masih mengadaptasi hal tersebut, hanya saja soal yang dimuat dalam kartu tersebut berbentuk QR Code. Dipilihnya $Q R$ Code pada pengembangan media ini karena $Q R$ Code memiliki beberapa keunggulan, diantaranya mudah dan bebas untuk dibuat, mudah diakses, dan sebagian besar telepon pintar dapat membacanya. Soal yang terdapat pada Media Pembelajaran QR Card Akuntansi tersebut hanya dapat dibaca dengan bantuan aplikasi $Q R$ Reader.
SMA Negeri 2 Bantul sudah menerapkan kurikulum terbaru yaitu Kurikulum 2013, di mana menurut kurikulum tersebut mata pelajaran Akuntansi hanya diadakan pada Kelas XII. Pada kenyataannya kebijakan SMA Negeri 2 Bantul tetap mengadakan mata pelajaran Akuntansi pada Kelas XI dengan alasan untuk mencicil materi yang harus diselesaikan di Kelas XII. Pembagian materi untuk Kelas XI adalah Akuntansi Sebagai Sistem Informasi, Persamaan Dasar Akuntansi dan Siklus Akuntansi Perusahaan Jasa, sedangkan pada kelas XII adalah Siklus Akuntansi Perusahaan Dagang. Sebenarnya tidak ada target dimana pada kelas XI materi tersebut harus benar-benar selesai, mengingat mata pelajaran Akuntansi pada kelas XI ditujukan untuk mencicil materi yang harus diselesaikan pada kelas XII. Jadi, bila materi pada kelas XI belum selesai maka dapat dilanjutkan pada kelas XII.

Setelah dilakukan observasi dan wawancara pada guru akuntansi SMA Negeri 2 Bantul diketahui proses pembelajaran Akuntansi di SMA Negeri 2 Bantul dapat dikatakan monoton karena pada setiap materi tahapan Siklus Akuntansi Perusahaan Jasa guru melaksanakan proses yang sama. Pada pertemuan pertama guru menjelaskan materi dengan bantuan LCD Proyektor, kemudian mengerjakan latihan soal bersama-sama dengan bantuan $L C D$ Proyektor dan papan tulis. Lalu pada pertemuan selanjutnya guru memberikan latihan soal mandiri. Kemudian pertemuan berikutnya dilaksanakan ulangan harian. Alasan guru memberikan banyak latihan soal karena akuntansi memerlukan banyak latihan soal agar siswa dapat menguasai keahlian yang ingin dicapai pada materi tersebut. Hanya saja proses pembelajaran yang monoton itulah yang menyebabkan siswa merasa bosan mengikuti proses pembelajaran akuntansi yang berlangsung. Terlebih pada siswa jurusan IPS di mana menurut guru mata pelajaran Akuntansi 
SMA Negeri 2 Bantul, Motivasi belajar Akuntansi siswa jurusan IPS lebih rendah dibandingkan dengan jurusan MIPA. Melihat keadaan tersebut, motivasi ekstrinsik perlu diberikan karena terdapat komponen pada proses pembelajaran yang kurang menarik (monoton) bagi siswa. Terdapat beberapa alternatif yang dapat dicoba untuk diterapkan, diantaranya dengan mengubah setrategi belajar mengajar agar menjadi sedikit kompetitif, memberikan hadiah, memberikan hukuman, dan bisa juga menggunakan media pembelajaran yang menarik perhatian siswa. Hanya saja, hal tersebut belum pernah dicoba untuk diterapkan.

Pada proses pembelajaran akuntansi di SMA Negeri 2 Bantul sendiri belum memanfaatkan media pembelajaran yang beragam. Guru hanya memanfaatkan alat yang disediakan oleh sekolah seperti $L C D$ Proyektor dan papan tulis. Belum terdapat inovasi pengembangan media pembelajaran yang memanfaatkan perkembangan teknologi oleh guru. Padahal guru tidak hanya dituntut untuk dapat menggunakan media yang sudah disediakan sekolah saja, namun guru juga dituntut untuk dapat mengembangkan media pembelajaran yang akan digunakan dan dapat membantu siswa dalam mencapai tujuan pembelajaran.

Pengembangan bukan berarti harus membuat suatu hal yang benar-benar baru dan belum pernah ada sebelumnya. Pengembangan dapat juga dilakukan dengan memodifikasi apa yang sudah ada, namun dikembangkan dan dikemas dengan mengikuti perkembangan zaman yang ada. Sesuai dengan apa yang diinginkan guru, siswa memerlukan banyak latihan soal agar siswa dapat menguasai keahlian yang akan dicapai pada suatu materi. Maka, penggunaan kartu soal dapat membantu siswa pada proses belajar, namun untuk megikuti perkembangan zaman saat ini pengemasan kartu soal dapat dibuat lebih menarik dengan menggunakan bantuan teknologi telepon pintar. Seperti halnya
Media Pembelajaran $Q R$ Card Akuntansi yang akan dikembangkan. Tentunya Media Pembelajaran $Q R$ Card Akuntansi dapat menjawab kebutuhan guru dan murid SMA Negeri 2 Bantul.

Berdasarkan paparan tersebut, maka penelitian dengan judul "Pengembangan Media Pembelajaran QR Card Akuntansi untuk Meningkatkan Motivasi Belajar Jurnal Penutup Siswa Kelas XII IPS SMA Negeri 2 Bantul Tahun Pelajaran 2018/2019" perlu dilakukan. Dikembangkannya Media Pembelajaran QR Card Akuntansi ini diharapkan dapat meningkatkan Motivasi Belajar Jurnal Penutup Siswa Kelas XII IPS SMA Negeri 2 Bantul. Selain itu, media $Q R$ Card Akuntansi juga dapat meningkatkan Motivasi Belajar Jurnal Penutup Siswa Kelas XII IPS SMA Negeri 2 Bantul. Selain itu, Media Pembelajaran $Q R$ Card Akuntansi juga diharapkan dapat digunakan oleh guru sebagai alternatif pilihan media pembelajaran yang dapat digunakan dalam berbagai sekenario pembelajaran akuntansi milik guru.

\section{METODE PENELITIAN}

\section{Jenis Penelitian}

Jenis penelitian yang digunakan untuk mengembangkan Media Pembelajaran $Q R$ Card Akuntansi ini adalah penelitian pengembangan (Research and Development). Menurut Borg \& Gall (1983: 772) "Educational research and development $(R \& D)$ is a process used to develop and validate educational products". Jadi penelitian pengembangan merupakan suatu proses yang digunakan untuk mengembangkan dan memvalidasi produk pendidikan. Pada penelitian ini produk yang dikembangkan adalah Media Pembelajaran QR Card Akuntansi.

\section{Waktu dan Tempat Penelitian}

Penelitian ini dilaksanakan di SMA Negeri 2 Bantul yang beralamat di Jalan RA Kartini, Trirenggo, Bantul, Bantul, 
Yogyakarta. Penelitian ini dilaksanakan pada Januari - Agustus 2018.

\section{Subjek dan Objek Penelitian}

Subjek dari penelitian ini adalah Siswa Kelas XII IPS SMA Negeri 2 Bantul dengan total 40 siswa. Objek pada penelitian pengembangan ini adalah Media Pembelajaran $Q R$ Card Akuntansi yang bertujuan untuk meningkatkan Motivasi Belajar Jurnal Penutup Siswa Kelas XII IPS SMA Negeri 2 Bantul.

\section{Prosedur Penelitian}

Penelitian ini merupakan penelitian pengembangan dengan menggunakan model pengembangan ADDIE (Analysis, Design, Development, Implementation, dan Evaluation) yang dikembangkan oleh Dick and Carry. Tahapan pengembangan Media Pembelajaran $Q R$ Card Akuntansi dengan model pengembangan ADDIE adalah sebagai berikut:

a. Tahap Analysis

Kegiatan utama pada tahap ini adalah menganalisis perlunya pengembangan media pembelajaran baru beserta kelayakan dan syarat-syarat pengembangannya. Maka, pada tahap ini peneliti perlu menganalisa permasalahan yang terjadi di Kelas XII IPS SMA Negeri 2 Bantul dan mencari informasi-informasi terkait terlebih dahulu. Setelah mengetahui berbagai informasi dan permasalahan yang terjadi peneliti dapat menganalisis perlunya pengembangan media pembelajaran baru beserta kelayakan dan syarat-syarat pengembangannya, media apa yang tepat untuk mengatasi masalah tersebut, dan menentukan materi apa yang akan dimuat dalam media tersebut.

b. Tahap Design

Berdasarkan hasil analisis pada tahapan pertama, selanjutnya dilakukan tahap desain atau perancangan. Pada tahap perancangan ini meliputi pembuatan konsep media, desain media, dan penyusunan soal dan jawaban. Berikut penjabaran dari tahap perencanaan:

1) Pembuatan Konsep Media

Media yang dikembangkan berupa media visual yaitu $Q R$ Card Akuntansi. Di mana Media Pembelajaran QR Card Akuntansi ini dimaksudkan sebagai pengembangan dari media pembelajaran kartu soal. Sama halnya dengan kartu soal, Media Pembelajaran $Q R$ Card Akuntansi ini juga memuat soal hanya saja soal yang dimuat berbentuk $Q R$ Code. Materi yang dimuat dalam Media Pembelajaran $Q R$ Card Akuntansi kali ini adalah materi Jurnal Penutup pada perusahaan jasa.

2) Pembuatan Desain Media

Media Pembelajaran $Q R$ Card Akuntansi ini berbentuk kartu dengan ukuran 13,5 $\times 9,5 \mathrm{~cm}$. Komponen yang terdapat pada kartu tersebut terdiri dari: logo $Q R$ Card Akuntansi, soal dalam bentuk $Q R$ Code, nama materi, dan kode nomor soal. Pada 1 paket Media Pembelajaran $Q R$ Card Akuntansi terdiri dari 10 kartu $Q R$ Card Akuntansi, saran penggunaan media dan kunci jawaban.

3) Penyusunan Soal dan Jawaban

Soal dan jawaban pada Media Pembelajaran QR Card Akuntansi ini merupakan soal dan jawaban mengenai materi Jurnal Penutup pada perusahaan jasa. Pembuatan soal dan jawaban pada media ini berdasarkan silabus Mata Pelajaran Ekonomi (Peminatan) SMA Negeri 2 Bantul. Soal dan jawaban dibuat atas berbagai sumber referensi materi.

c. Tahap Development

1) Pembuatan Produk

Pada tahap ini, Media Pembelajaran $Q R$ Card Akuntasi dibuat sesuai dengan konsep dan desain yang telah dirancang. 
2) Validasi Tahap I

Pada validasi tahap I, hasil awal dari Media Pembelajaran $Q R$ Card Akuntasi divalidasi oleh ahli materi dan ahli media, di mana ahli materi dan ahli media adalah dosen yang memiliki keahlian di bidang tersebut. Hasil dari validasi tahap I adalah berupa kritik dan saran yang dapat digunakan sebagai dasar melakukan revisi tahap I.

3) Revisi Tahap I

Revisi tahap I dilakukan berdasarkan kritik dan saran yang telah diberikan oleh ahli materi dan ahli media.

4) Validasi Tahap II

Pada validasi tahap II, Media Pembelajaran $Q R$ Card Akuntasi yang telah direvisi tahap satu divalidasi kembali oleh praktisi pembelajaran akuntansi, dalam hal ini adalah Guru Akuntansi SMA Negeri 2 Bantul. Kritik dan saran dari Guru Akuntasni SMA Negri 2 Bantul dapat dijadikan sebagai dasar melakukan revisi tahap II.

5) Revisi Tahap II

Pada revisi tahap II, Media Pembelajaran $Q R$ Card Akuntasi kembali direvisi berdasarkan kritik dan saran yang diberikan oleh praktisi pembelajaran akuntansi. Media Pembelajaran $Q R$ Card Akuntasi hasil revisi tahap II ini selanjutnya siap untuk diujicobakan kepada siswa melalui uji coba kelompok kecil.

6) Uji Coba Kelompok Kecil

Uji coba kelompok kecil dilaksanakan sebagai tindak lanjut dari persetujuan para ahli terhadap media yang dikembangkan. Uji coba kelompok kecil dilaksanakan dengan melibatkan subjek penelitian yaitu siswa kelas XII IPS 1. Tujuan dari uji coba kelompok kecil adalah untuk mengetahui kelayakan Media Pembelajaran $Q R$ Card Akuntansi.
7) Revisi Tahap III

Pada revisi tahap III, Media Pembelajaran $Q R$ Card Akuntasi kembali direvisi berdasarkan kritik dan saran yang diberikan oleh siswa kelas XII IPS 1. Media Pembelajaran $Q R$ Card Akuntasi hasil revisi tahap III ini selanjutnya siap untuk diimplementasikan kepada siswa melaui uji coba lapangan.

\section{d. Tahap Implementation}

Pada tahap ini, Media Pembelajaran QR Card Akuntansi diimplementasikan kepada 20 siswa Kelas XII IPS 2 SMA Negeri 2 Bantul. Peneliti berperan sebagai fasilitator dan memantau jalannya kegiatan pembelajaran dengan menggunakan Media Pembelajaran $Q R$ Card Akuntansi. Pada tahap ini pula dibagikan angket Motivasi Belajar Jurnal Penutup pada saat sebelum penggunaan Media Pembelajaran $Q R$ Card Akuntansi dan sesudah proses pembelajaran menggunakan $Q R$ Card Akuntansi.

\section{e. Tahap Evaluation}

Pada tahap ini peneliti mengukur ketercapaian tujuan pengembangan produk Media Pembelajaran QR Card Akuntasi. Produk tersebut diukur berdasarkan angket Motivasi Belajar Jurnal Penutup yang telah diisi oleh siswa pada tahap implementasi untuk mengetahui peningkatan Motivasi Belajar Jurnal Penutup setelah dan sebelum penerapan Media Pembelajaran $Q R$ Card Akuntasi. Hasil angket tersebut kemudian dianalisis menggunakan rumus gain score untuk mengetahui peningkatan Motivasi Belajar Jurnal Penutup.

\section{Teknik Pengumpulan Data}

Penelitian ini menggunakan teknik pengumpulan data dengan angket. Kuisioner (angket) adalah teknik pengumpulan data yang dilakukan dengan 
cara memberi seperangkat pertanyaan atau pernyataan tertulis kepada responden untuk dijawabnya (Sugiyono, 2014: 142). Angket digunakan untuk mengetahui kelayakan media yang dikembangkan dan mengukur motivasi belajar siswa. Pengumpulan data dengan angket pada penelitian ini digunakan untuk mengetahui kelayakan Media Pembelajaran QR Card Akuntansi oleh ahli materi, ahli media, dan praktisi pembelajaran akuntansi sebagai pedoman perbaikan Media Pembelajaran QR Card Akuntansi. Selain itu penggunaan angket juga bertujuan untuk mengukur Motivasi Belajar Jurnal Penutup.

Data yang dikumpulkan dalam penelitian ini merupakan data kuantitatif dan kualitatif. Data kuantitatif sebagai data pokok pada penelitian ini berupa data penilaian kelayakan Media Pembelajaran QR Card Akuntansi dari ahli materi, ahli media, praktisi pembelajaran akuntansi, dan siswa serta data Motivasi Belajar Jurnal Penutup. Data kualitatif merupakan data tentang proses pengembangan Media Pembelajaran $Q R$ Card Akuntansi yang berupa kritik dan saran dari ahli materi, ahli media, praktisi pembelajaran akuntansi, dan siswa.

\section{Instrumen Penelitian}

Instrumen yang digunakan untuk mengumpulkan data pada penelitian ini adalah angket. Angket diberikan kepada ahli materi, ahli media, praktisi pembelajaran akuntansi, dan siswa. Angket berupa lembar checklist pada penelitian ini menggunakan skala Likert yang telah dimodifikasi dengan 4 alternatif jawaban. Angket-angket yang dibutuhkan pada penalitian ini adalah angket validasi kelayakan media oleh ahli materi, ahli media, praktisi pembelajaran akuntansi, serta siswa, dan angket motivasi belajar jurnal penutup.

\section{Teknik Analisis Data}

Teknik analisis data yang digunakan dalam penelitian ini adalah teknik analisis deskriptif kuantitatif. Berikut adalah langkah-langkah analisis data yang diperlukan:

a. Analisis data penilaian kelayakan produk Media Pembelajaran $Q R$ Card Akuntansi

Data penilaian kelayakan produk diperoleh dari hasil isian angket oleh ahli materi, ahli media, praktisi pembelajaran akuntansi, dan siswa. Selanjutnya data dianalisis dengan mengikuti langkah-langkah berikut:

a. Menghitung rata-rata skor setiap indikator dengan rumus:

\begin{tabular}{|c|c|c|c|}
\hline $\begin{array}{l}\text { Sk } \\
\text { or }\end{array}$ & Interval Skor & Nilai & Kategori \\
\hline 4 & $(\mathrm{Mi}+3 \mathrm{SDi}) \geq \mathrm{X} \geq(\mathrm{Mi}$ & A & $\begin{array}{c}\text { Sangat } \\
\text { Baik }\end{array}$ \\
\hline 3 & $(\mathrm{Mi}+1,5 \mathrm{SDi})>\mathrm{X} \geq \mathrm{M}$ & $\mathrm{B}$ & Baik \\
\hline 2 & $\mathrm{Mi}>\mathrm{X} \geq(\mathrm{Mi}-1,5 \mathrm{SDi})$ & $\mathrm{C}$ & $\begin{array}{c}\text { Kurang } \\
\text { Baik }\end{array}$ \\
\hline 1 & $(\mathrm{Mi}-1,5 \mathrm{SDi})>\mathrm{X} \geq(\mathrm{M}$ & $\mathrm{D}$ & $\begin{array}{c}\text { Sangat } \\
\text { Tidak } \\
\text { Baik }\end{array}$ \\
\hline & $\begin{array}{l}\bar{x}=\frac{\sum x}{n} \\
\text { Keterangan: } \\
\bar{x}=\text { Skor ra } \\
\sum x=\text { Jumlah } \\
n=\text { Jumlah } \\
\text { b. Menginterpret } \\
\text { kuantitatif jur } \\
\text { tiap aspek der } \\
\text { kriteria sebaga }\end{array}$ & $\begin{array}{l}\text { a-rata } \\
\text { skor } \\
\text { butir p } \\
\text { asikan } \\
\text { lah ra }\end{array}$ & $\begin{array}{l}\text { hilaian } \\
\text { secara } \\
\text {-rata skor } \\
\text { gggunakan } \\
\text { t: }\end{array}$ \\
\hline
\end{tabular}

\section{Tabel 1. Konversi Skor pada Skala 4}

Sumber: Lukman \& Ishartiwi (2014: 112)

Keterangan:

$M i \quad=$ Mean Ideal

$S D i=$ Standar Deviasi Ideal

$X \quad=$ jumlah skor yang diperoleh

$M i=\frac{1}{2}$ (skor maksimal ideal +

skor minimal ideal)

$S D i=\frac{1}{6}$ (skor maksimal ideal -

skor minimal ideal) 
Berdasarkan tabel 1, diperoleh kriteria kevalidan produk dengan pengembangan pada tabel 2 berikut:

Tabel 2. Kelayakan Produk

\begin{tabular}{|c|c|}
\hline Interval Skor & Kategori \\
\hline $4 \geq X \geq 3,25$ & Sangat Layak \\
\hline $3,25>X \geq 2,5$ & Layak \\
\hline $2,5>X \geq 1,75$ & Tidak Layak \\
\hline $1,75>X \geq 1$ & $\begin{array}{c}\text { Sangat Tidak } \\
\text { Layak }\end{array}$ \\
\hline
\end{tabular}

Berdasarkan tabel 2 tersebut, media pembelajaran $Q R$ Card Akuntansi dikatakan layak digunakan, apabila hasil penilaian menunjukkan kriteria minimal layak.

c. Analisis data angket Motivasi Belajar Jurnal Penutup

Angket Motivasi Belajar Jurnal Penutup merupakan pernyataan tertutup dengan alternatif jawaban dan skoring sebagai berikut:

Tabel 3. Alternatif Jawaban dan Skoring Angket Motivasi Belajar Jurnal Penutup

\begin{tabular}{|c|c|c|}
\hline \multirow{2}{*}{$\begin{array}{c}\text { Alternatif } \\
\text { Jawaban }\end{array}$} & $\begin{array}{c}|c| \\
\text { Pernyataan } \\
\text { Positif }\end{array}$ & $\begin{array}{c}\text { Pernyataa } \\
\text { n Negatif }\end{array}$ \\
\hline $\begin{array}{c}\text { Sangat } \\
\text { Setuju (SS) }\end{array}$ & 4 & 1 \\
\hline Setuju (S) & 3 & 2 \\
\hline $\begin{array}{c}\text { Tidak } \\
\text { Setuju (TS) }\end{array}$ & 2 & 3 \\
\hline $\begin{array}{c}\text { Sangat } \\
\text { Tidak } \\
\text { Setuju } \\
\text { (STS) }\end{array}$ & 1 & 4 \\
\hline
\end{tabular}

Analisis data angket peserta didik menggunakan analisis deskriptif. Hasil dari pengisian angket Motivasi Belajar awal dan akhir kemudian dianalisis dengan menghitung nilai gain $(g)$ menggunakan rumus berikut:

$$
g=\frac{\text { skor akhir }- \text { skor awal }}{\text { skor maksimum - skor awal }}
$$

(Hake, 2012)

Hasil perhitungan dengan menggunakan rumus di atas kemudian diinterpretasikan ke dalam kategori kriteria nilai gain yang ditunjukkan pada tabel 4 berikut:

Tabel 4. Kriteria Nilai Gain

\begin{tabular}{|c|c|}
\hline Nilai $\boldsymbol{g}$ & Kriteria \\
\hline$g \geq 0,7$ & Tinggi (high) \\
\hline $0,7<g \leq$ & Sedang (medium) \\
0,3 & \\
\hline$g<0,3$ & Rendah (low) \\
\hline
\end{tabular}

Sumber: Ha

Guna mengetahui peningkatan Motivasi Belajar Jurnal Penutup signifikan atau tidak, perlu dilakukan dengan uji t. Penghitungan uji $t$ dilakukan dengan suatu program pengolah data. Jika, hasilnya signifikan berarti terdapat peningkatan Motivasi Belajar Jurnal Penutup. Sebagaimana yang dikemukakan oleh Larson-Hall (2010: 241) " $A t$ test cen tell us if the differences between the two scores are big enough that we can assume ... that scores at Time 1 differ from scores at Time 2."

\section{HASIL PENELITIAN DAN PEMBAHASAN}

Pengembangan Media Pembelajaran $Q R$ Card Akuntansi ini merupakan adaptasi dari model pengembangan ADDIE yang dikembangkan oleh Dick and Carry. ADDIE merupakan singkatan dari Analysis, Design, Development, Implementation, dan Evaluation. Berikut adalah tahapan pengembangan Media Pembelajaran QR Card Akuntansi dengan model pengembangan ADDIE:

1. Tahap Analisis (Analysis) 
Pada tahap analisis, peneliti melakukan observasi di kelas XI IPS 1 SMA Negeri 2 Bantul Tahun Pelajaran 2017/2018 dan melakukan wawancara kepada guru Akuntansi SMA Negeri 2 Bantul. Observasi dan wawancara dilaksanakan pada 19 Januari 2018. Terdapat 20 siswa hadir dan 1 siswa absen. Aktivitas yang dilakukan siswa pada hari itu adalah mengerjakan tugas mandiri. Pada awal memasuki kelas, guru membuka pelajaran dengan salam dilanjutkan dengan menjelaskan pembelajaran pada pertemuan kali itu. Kemudian guru melakukan absensi, menjelaskan aturan pengerjaan tugas mandiri, dan membagikan soal dan lembar jawab kepada siswa. Saat guru memberitahukan kegiatan pada hari itu adalah mengerjakan tugas mandiri ekspresi wajah siswa berubah jadi tegang dan panik. Hal tersebut mengindikasikan ketidaksiapan siswa untuk mengerjakan soal secara mandiri. Pembelajaran berjalan dengan kondusif meskipun harus terpotong jam istirahat.

Setelah wawancara dengan guru Akuntansi, diketahui bahwa proses pembelajran akuntansi yang dilaksanakan adalah menjelaskan materi, mengerjakan latihan soal, mengerjakan tugas mandiri, kemudian dilaksanakan ulangan harian, begitu seterusnya hingga materi satu Siklus Perusahaan Jasa selesai. Hal yang mendasari diberikannya banyak latihan soal adalah tujuan dari pembelajaran Akuntansi yang diberikan yaitu agar siswa dapat menguasai keterampilan pencatatan dalam Akuntansi. Selain hal tersebut, diketahui pula bahwa guru belum memanfaatkan media pembelajaran yang beragam dan motivasi belajar siswa jurusan IPS lebih rendah dari jurusan MIPA. Media pembelajaran yang digunakan guru selama ini adalah power point, papan tulis, dan handout yang dibuat oleh guru. Guru juga memberitahukan bahwa proses pembelajaran di kelas XI IPS 2 seringkali kurang kondusif dikarenakan kurangnya perhatian siswa saat guru menyampaikan materi di depan kelas, dan saat diberikan latihan soal maupun tugas mandiri.

Berdasarkan berbagai informasi yang didapat tersebut diketahui bahwa terdapat kesenjangan yaitu motivasi belajar siswa jurusan IPS dan MIPA, di mana jurusan IPS memiliki motivasi belajar yang lebih rendah dari jurusan MIPA terlebih pada kelas XI IPS 2. Rendahnya motivasi belajar tersebut dapat disebabkan karena proses pembelajaran yang monoton dan kurang bervariasinya media yang digunakan guru. Dengan demikian, perlu dikembangkan media pembelajaran yang sesuai dengan tujuan pembelajaran akuntansi dan dapat menigkatkan motivasi belajar siswa. Peneliti memilih mengembangkan Media Pembelajaran $Q R$ Card Akuntansi karena sesuai dengan proses pembelajaran yang dipilih guru yaitu dengan memberikan latihan soal, hanya saja kali ini latihan soal diberikan dengan cara yang lebih menyenangkan.

2. Tahap Desain (Design)

a. Pembuatan Konsep

Media yang dikembagkan merupakan media visual yaitu Media Pembelajaran $Q R$ Card Akuntansi. Pengembangan Media Pembelajaran $Q R$ Card Akuntansi dimaksudkan sebagai pengembangan dari media kartu soal yang sudah ada. Sama halnya dengan kartu soal, Media Pembelajaran $Q R$ Card Akuntansi merupakan media berbentuk kartu yang memuat soal, hanya saja soal yang dimuat dalam Media Pembelajaran $Q R$ Card Akuntansi berbentuk $Q R$ Code.

Media Pembelajaran $Q R$ Card Akuntansi dapat digunakan dengan bantuan telepon pintar yang sudah terpasang aplikasi $Q R$ Reader atau 
QR Scanner. Aplikasi tersebut dapat diunduh pada Play Store ataupun App Store. Cara penggunaannya adalah dengan membuka aplikasi $Q R$ Reader atau $Q R$ Scanner kemudian menggarahkan kamera telepon pintar ke Media Pembelajaran $Q R$ Card Akuntansi untuk membidik $Q R$ Code yang tertera pada kartu.

b. Pembuatan Desain Media

Media Pembelajaran $Q R$ Card Akuntansi merupakan media berupa kartu dengan ukuran 13,5 × 9,5 cm. Komponen yang terdapat pada kartu tersebut terdiri dari: brand produk, soal Jurnal Penutup dalam bentuk QR Code, judul materi, dan kode soal. Pada 1 paket Media Pembelajaran $Q R$ Card Akuntansi terdiri dari 10 kartu $Q R$ Card Akuntansi yang terdiri dari 5 kartu yang berisi soal teori dan 5 kartu yang berisi soal praktik, saran penggunaan serta kunci jawaban.

c. Penyusunan Soal dan Jawaban

Materi yang dipilih pada penelitian pengembangan kali ini adalah materi Jurnal Penutup. Penyusunan soal dan jawaban Jurnal Penutup berdasarkan dari Silabus Mata Pelajaran Ekonomi (Peminatan) SMA Negeri 2 Bantul. Soal dan jawaban disusun dan dikembangkan berdasarkan berbagai sumber buku referensi. Tahap Pengembangan (Development)

Pada tahap ini pembuatan produk Media Pembelajaran $Q R$ Card Akuntansi mulai dilaksanakan. Pembuatan desain Media Pembelajaran QR Card Akuntansi direalisasikan denagan menggunakan aplikasi CorelDraw X7. Pemilihan tema desain, warna, dan jenis font sangat mempengaruhi hasil akhir dari Media Pembelajaran $Q R$ Card Akuntansi. Kemudian, untuk membuat saran penggunaan dan kunci jawaban pada awalnya dibuat menggunakan Microsoft Word, namun setelah mendapatkan saran dari ahli media maka saran penggunaan dan kunci jawaban dibuat menggunakan bantuan aplikasi CorelDraw X7. Menggunakan kertas ukuran A3, saran penggunaan dan kunci jawaban didesain dengan tampilan seperti brosur.

Setelah proses pembuatan produk selesai dilaksanakan, selanjutnya adalah melaksanakan validasai tahap I yang diikuti dengan revisi tahap I. Validasi tahap I adalah validasi oleh Ahli Materi dan Ahli Media. Ahli Materi dan Ahli Media yang dipilih adalah dosen Pendidikan Akuntansi, Fakultas Ekonomi, Universitas Negeri Yogyakarta yang memiliki keahlian di bidang tersebut. Proses validasi oleh Ahli Materi dilaksanakan dengan menyerahkan silabus, materi Jurnal Penutup, soal dan jawaban, serta angket validasi sebagai alat penilaian kelayakan materi yang dimuat dalam media kepada Ahli Materi. Selanjutnya proses validasi oleh Ahli Media dengan menyerahkan Media Pembelajaran $Q R$ Card Akuntansi dan angket validasi sebagai alat penilaian kelayakan media yang dikembangkan.

Angket validasi untuk Ahli Materi terdiri dari 16 pernyataan di mana 14 pernyataan merupakan aspek penilaian materi dan evaluasi, dan 2 pernyataan merupakan aspek penilaian bahasa. Berikut adalah ringkasan hasil validasi Ahli Materi:

Tabel 5. Hasil Validasi Ahli Materi

\begin{tabular}{|c|l|c|c|c|}
\hline No. & $\begin{array}{c}\text { Aspek } \\
\text { Penilai- } \\
\text { an }\end{array}$ & $\begin{array}{c}\text { Jum- } \\
\text { lah } \\
\text { Skor }\end{array}$ & $\begin{array}{c}\text { Rata- } \\
\text { Rata } \\
\text { Skor }\end{array}$ & $\begin{array}{c}\text { Kate- } \\
\text { gori }\end{array}$ \\
\hline 1 & $\begin{array}{l}\text { Materi } \\
\text { dan } \\
\text { Evaluasi }\end{array}$ & 50 & 3,57 & $\begin{array}{c}\text { Sangat } \\
\text { Layak }\end{array}$ \\
\hline 2 & Bahasa & 6 & 3,00 & Layak \\
\hline \multicolumn{2}{|c|}{ Total } & 56 & 3,50 & $\begin{array}{l}\text { Sangat } \\
\text { Layak }\end{array}$ \\
\hline
\end{tabular}


Sumber: Data primer yang diolah

Berdasarkan tabel 5, secara keseluruhan hasil validasi oleh Ahli Materi berdasarkan aspek Materi dan Evaluasi, serta Bahasa memperoleh nilai rata-rata skor 3,5. Hasil penilaian tersebut menunjukkan bahwa Media Pembelajaran $Q R$ Card Akuntansi dari hasil validasi oleh Ahli Materi termasuk dalam kategori sangat layak.

Angket validasi untuk Ahli Media terdiri dari 16 pernyataan di mana 6 pernyataan merupakan aspek penilaian rekayasa media, dan 10 pernyataan merupakan aspek penilaian komunikasi visual. Berikut adalah ringkasan hasil validasi Ahli Media:

Tabel 6. Hasil Validasi Ahli Media

\begin{tabular}{|c|l|c|c|c|}
\hline $\begin{array}{c}\text { No } \\
\cdot\end{array}$ & $\begin{array}{c}\text { Aspek } \\
\text { Penilai- } \\
\text { an }\end{array}$ & $\begin{array}{c}\text { Jum- } \\
\text { lah } \\
\text { Skor }\end{array}$ & $\begin{array}{c}\text { Rata- } \\
\text { Rata } \\
\text { Skor }\end{array}$ & Kategori \\
\hline 1 & $\begin{array}{l}\text { Rekayas } \\
\text { a Media }\end{array}$ & 21 & 3,50 & $\begin{array}{l}\text { Sangat } \\
\text { Layak }\end{array}$ \\
\hline 2 & $\begin{array}{l}\text { Komuni } \\
\text { kasi } \\
\text { Visual }\end{array}$ & 36 & 3,60 & $\begin{array}{l}\text { Sangat } \\
\text { Layak }\end{array}$ \\
\hline \multicolumn{2}{|c|}{ Total } & 57 & 3,56 & $\begin{array}{l}\text { Sangat } \\
\text { Layak }\end{array}$ \\
\hline
\end{tabular}

Sumber: Data primer yang diolah

Berdasarkan tabel 6, secara keseluruhan hasil validasi Ahli Media berdasarkan aspek rekayasa media, dan komunikasi visual memperoleh nilai rata-rata skor 3,56. Hasil penilaian tersebut menunjukkan bahwa Media Pembelajaran $Q R$ Card Akuntansi dari hasil validasi oleh Ahli Media termasuk dalam kategori sangat layak.

Setelah validasi tahap I dan revisi tahap I selesai dilaksanakan, maka selanjutnya adalah validasi tahap II yang diikuti dengan revisi tahap II. Validasi tahap II ini dilakukan oleh praktisi pembelajran akuntansi. Proses validasi dilakukan dengan menyerahkan materi Jurnal Penutup, soal dan jawaban, Media Pembelajaran $Q R$ Card Akuntansi, dan angket validasi sebagai alat penilaian kelayakan media yang dikembangkan.

Angket validasi untuk Praktisi Pembelajaran Akuntansi terdiri dari 25 pernyataan di mana 14 pernyataan merupakan aspek penilaian materi dan evaluasi, 2 pernyataan merupakan aspek penilaian bahasa, 6 pernyataan merupakan aspek penilaian rekayasa media, dan 3 pernyataan merupakan aspek komunikasi visual. Berikut adalah ringkasan hasil validasi Praktisi Pembelajaran Akuntansi:

Tabel 7. Hasil Validasi Praktisi Pembelajaran Akuntansi

\begin{tabular}{|c|l|c|c|c|}
\hline $\begin{array}{c}\text { No } \\
\cdot\end{array}$ & $\begin{array}{c}\text { Aspek } \\
\text { Penilai- } \\
\text { an }\end{array}$ & $\begin{array}{c}\text { Jum- } \\
\text { lah } \\
\text { Skor }\end{array}$ & $\begin{array}{c}\text { Rata- } \\
\text { Rata } \\
\text { Skor }\end{array}$ & $\begin{array}{c}\text { Katego- } \\
\text { ri }\end{array}$ \\
\hline 1 & $\begin{array}{l}\text { Materi } \\
\text { dan } \\
\text { Evaluasi }\end{array}$ & 50 & 3,57 & $\begin{array}{c}\text { Sangat } \\
\text { Layak }\end{array}$ \\
\hline 2 & Bahasa & 6 & 3,00 & Layak \\
\hline 3 & $\begin{array}{l}\text { Rekayas } \\
\text { a Media }\end{array}$ & 23 & 3,83 & $\begin{array}{l}\text { Sangat } \\
\text { Layak }\end{array}$ \\
\hline 4 & $\begin{array}{l}\text { Komuni } \\
\text { kasi } \\
\text { Visual }\end{array}$ & 11 & 3,67 & $\begin{array}{l}\text { Sangat } \\
\text { Layak }\end{array}$ \\
\hline \multicolumn{2}{|c|}{ Total } & 90 & 3,60 & $\begin{array}{l}\text { Sangat } \\
\text { Layak }\end{array}$ \\
\hline
\end{tabular}

Sumber: Data primer yang diolah

Berdasarkan tabel 7, secara keseluruhan hasil validasi Praktisi Pembelajaran Akuntansi berdasarkan aspek materi dan evaluasi, bahasa, rekayasa media, dan komunikasi visual memperoleh nilai rata-rata skor 3,60. Hasil penilaian tersebut menunjukkan bahwa Media Pembelajaran $Q R$ Card Akuntansi dari hasil validasi oleh Praktisi Pembelajaran Akuntansi termasuk dalam kategori sangat layak. 
Media Pembelajaran QR Card Akuntansi yang telah selesai direvisi atas saran Ahli Materi, Ahli Media, dan Praktisi Pembelajaran Akuntansi selanjutnya diujikan pada siswa dengan uji coba kelompok kecil. Uji coba kelompok kecil ditujukan untuk mengetahui kelayakan produk sebelum diimplementasikan. Uji coba kelompok kecil ini dilaksanakan pada kelas XII IPS 1 SMA Negeri 2 Bantul dengan jumlah responden 20 siswa. Hasil uji coba kelompok kecil didapatkan melalui angket kelayakan media yang diberikan pada siswa setelah selesai melaksanakan proses pembelajaran dengan bantuan Media Pembelajaran QR Card Akuntansi. Dari angket tersebut, data diolah dan diperloleh ringkasan hasil penilaian kelayakan media oleh siswa melalui uji coba kelompok kecil seperti berikut:

Tabel 8. Hasil Penilaian Kelayakan Media oleh Siswa

\begin{tabular}{|c|l|c|c|c|}
\hline $\begin{array}{c}\text { No } \\
\cdot\end{array}$ & $\begin{array}{c}\text { Aspek } \\
\text { Penilaian }\end{array}$ & $\begin{array}{c}\text { Jum- } \\
\text { lah } \\
\text { Skor }\end{array}$ & $\begin{array}{c}\text { Rata- } \\
\text { Rata } \\
\text { Skor }\end{array}$ & Kategori \\
\hline 1 & $\begin{array}{l}\text { Pembelaja } \\
\text { ran }\end{array}$ & 329 & 3,29 & $\begin{array}{c}\text { Sangat } \\
\text { Layak }\end{array}$ \\
\hline 2 & $\begin{array}{l}\text { Rekayasa } \\
\text { Media }\end{array}$ & 270 & 3,38 & $\begin{array}{c}\text { Sangat } \\
\text { Layak }\end{array}$ \\
\hline 4 & $\begin{array}{l}\text { Komunikas } \\
\text { i Visual }\end{array}$ & 538 & 3,36 & $\begin{array}{l}\text { Sangat } \\
\text { Layak }\end{array}$ \\
\hline \multicolumn{2}{|c|}{ Total } & $\mathbf{1 1 3 7}$ & $\mathbf{3 , 3 4}$ & $\begin{array}{c}\text { Sangat } \\
\text { Layak }\end{array}$ \\
\hline
\end{tabular}

Sumber: Data primer yang diolah

Berdasarkan tabel 8, diketahui keseluruhan hasil penilaian kelayakan media oleh siswa berdasarkan aspek pembelajaran, rekayasa media, dan komunikasi visual memperoleh nilai rata-rata skor 3,34. Hasil penilaian tersebut menunjukkan bahwa Media Pembelajaran QR Card Akuntansi dari hasil penilaian kelayakan media oleh siswa termasuk dalam kategori sangat layak. Maka Media Pembelajaran $Q R$ Card Akuntansi sudah siap untuk diimplementasikan pada uji coba lapangan.

3. Tahap Implementasi (Implementation)

Tahap implementasi dilaksanakan di kelas XII IPS 2 dengan jumlah responden 20 siswa. Tahap implementasi dimulai dengan membagi siswa menjadi 5 kelompok. Setelah siswa duduk secara berkelompok, peneliti membagikan angket Motivasi Belajar Jurnal Penutup sebelum menggunakan Media Pembelajaran $Q R$ Card Akuntansi dan mereview materi Jurnal Penutup. Kemudian peneliti menjelaskan aturan bermain dengan menggunakan Media Pembelajaran $Q R$ Card Akuntansi sambil mengumpulkan angket Motivasi Belajar Jurnal Penutup sebelum menggunakan Media Pembelajaran QR Card Akuntansi dan membagikan lembar jawab kepada siswa. Setelah semua siswa paham dengan aturan bermain, maka pembelajaran dengan menggunakan bantuan Media Pembelajaran QR Card Akuntansi dimulai.

Semua siswa terlihat senang dan berpartisipasi secara aktif dalam pembelajaran yang berlangsung. Setelah selesai pembelajaran, tiap kelompok mengumpulkan lembar jawab, kemudian dibagikan kembali angket Motivasi Belajar Jurnal Penutup setelah menggunakan Media Pembelajaran $Q R$ Card Akuntansi untuk diisi. Setelah selesai mengisi dan mengumpulkan angket Motivasi Belajar Jurnal Penutup sesudah menggunakan Media Pembelajaran QR Card Akuntansi siswa diperkenankan untuk istirahat.

4. Tahap Evalusai (Evaluation)

Tahap evaluasi ini adalah tahap dimana peneliti mengukur ketercapaian tujuan pengembangan produk Media Pembelajaran $Q R$ Card Akuntansi. Produk tersebut diukur berdasarkan angket Motivasi Belajar 
Jurnal Penutup sebelum dan sesudah menggunakan Media Pembelajaran QR Card Akuntansi yang telah diisi oleh siswa kelas XII IPS 2. Angket menggunakan skala Likert yang telah dimodifikasi dengan 4 alternatif jawaban, dan terdiri dari 18 pernyataan diantaranya terdapat 2 pernyataan negatif. Angket telah melalui uji validasi instrumen dan diketahui koefisien reliabilitasnya $0,916>0,5$ berarti instrumen tersebut cukup andal/reliabel. Hasil dari kedua jenis angket tersebut kemudian dianalisis menggunakan rumus gain score untuk menegtahui peningkatan Motivasi Belajar Jurnal Penutup dan dilakukan pula uji beda dengan uji $t$ berpasangan untuk mengetahui signifikansi perubahan peningkatan Motivasi Belajar Jurnal Penutup.

$g=\frac{79,65-75,42}{100-75,42}$

$g=\frac{4,23}{24,58}$

$g=0,17$

Berdasarkan hasil dari perhitungan gain score tersebut, diketahui nilai gain adalah 0,17 maka peningkatan Motivasi Belajar Jurnal Penutup Siswa Kelas XII IPS 2 SMA Negeri 2 Bantul termasuk dalam kategori rendah karena $\mathrm{g}<0,3$. Namun, untuk mengetahui apakah terdapat perubahan motivasi yang signifikan maka dilakukan pula uji beda dengan uji $\mathrm{t}$ berpasangan. Berikut adalah ringkasan hasil olah data dari uji $\mathrm{t}$ berpasangan dengan menggunakan SPSS Statistic 22:

Tabel 9. Hasil Olah Data Uji t Berpasangan

\begin{tabular}{|c|c|c|c|c|c|c|}
\hline & \multicolumn{2}{|c|}{ Mean } & \multirow[b]{2}{*}{$\begin{array}{c}\text { Corr } \\
\text { elatio } \\
\mathbf{n}\end{array}$} & \multirow[b]{2}{*}{ Sig. } & \multirow[b]{2}{*}{$\mathbf{T}$} & \multirow[b]{2}{*}{$\begin{array}{c}\text { Sig. } \\
(2- \\
\text { tailed }\end{array}$} \\
\hline & $\begin{array}{c}\text { Seb } \\
\text { elu } \\
\text { m } \\
\end{array}$ & $\begin{array}{c}\text { Sesu } \\
\text { dah }\end{array}$ & & & & \\
\hline Pair 1 & 54,30 & 57,35 & ,919 &, 000 & $-5,196$ & ,000 \\
\hline
\end{tabular}

Sumber: Data primer yang diolah
Berdasarkan tabel 9, diketahui $t_{\text {hitung }}=-5,196>t_{\text {tabel }}=2,086$ dan sig $=0,000<0,05$ maka terdapat perbedaan Motivasi Belajar Jurnal Penutup yang signifikan antara sebelum dan sesudah menggunakan Media Pembelajaran $Q R$ Card Akuntansi. Kesimpulannya, Media Pembelajaran $Q R$ Card Akuntansi dapat meningkatkan Motivasi Belajar Jurnal Penutup Siswa Kelas XII IPS SMA Negeri 2 Bantul Tahun Pelajaran 2018/2019.

\section{SIMPULAN DAN SARAN}

\section{Simpulan}

Media Pembelajaran $Q R$ Card Akuntansi pada Materi Jurnal Penutup berdasarkan penilaian Ahli Materi, Ahli Media, dan Praktisi Pembelajaran Akuntansi masing-masing memperoleh rata-rata skor 3,50 (Sangat Layak); 3,56 (Sangat Layak); 3,60 (Sangat Layak). Selain itu, penilian kelayakan Media Pembelajaran $Q R$ Card Akuntansi oleh siswa melalui uji coba kelompok kecil juga menunjukkan rata-rata skor 3,34 dan termasuk dalam kategori "Sangat Layak". Maka, dapat disimpulkan bahwa Media Pembelajaran $Q R$ Card Akuntansi sangat layak digunakan sebagai media pembelajaran di SMA Negeri 2 Bantul.

Media Pembelajaran $Q R$ Card Akuntansi terbukti dapat meningkatkan Motivasi Belajar Jurnal Penutup Siswa Kelas XII IPS SMA Negeri 2 Bantul sebesar $4,23 \%$ hasil tersebut didapat dari persentase rerata motivasi sesudah dikurangi persentase rerata motivasi sebelum. Berdasarkan nilai gain diketahui nilainya sebesar $0,17<0,3$ dan termasuk dalam kategori rendah. Selanjutnya, setelah dilakukan uji beda melalui uji $\mathrm{t}$ berpasangan menunjukkan pengukuran yang singnifikan. Maka, dapat disimpulkan bahwa Media Pembelajaran $Q R$ Card Akuntansi dapat meningkatkan Motivasi Belajar Jurnal Penutup Siswa Kelas XII IPS SMA Negeri 2 Bantul Tahun Pelajaran 
2018/2019 meskipun peningkatannya relatif rendah.

\section{Saran}

a. Perlu adanya pengembangan Media Pembelajaran $Q R$ Card Akuntansi lebih lanjut sehingga materi tidak hanya terbatas pada materi Jurnal Penutup pada Perusahaan Jasa saja.

b. Pengukuran motivasi tidak hanya pada satu kelas saja sehingga dapat diketahui perbedaan tingkat Motivasi Belajar Jurnal Penutup Siswa.

c. Pada penelitian selanjutnya, uji coba media dapat dilakukan lebih luas lagi sehingga menghasilkan media pembelajaran yang dapat digunakan secara luas.

d. Pada penelitian selanjutnya, diharapkan terdapat pengembangan aplikasi $Q R$ Reader atau $Q R$ Scanner yang khusus untuk membaca dan mengerjakan soal pada $Q R$ Card Akuntansi sehingga tidak diperlukan lembar jawab yang dikerjakan secara manual.

\section{DAFTAR PUSTAKA}

Borg, W.R. \& Gall, M.D. (1983). Educational Research. New York: Longman Inc.

Hake, R. (2012). Analyzing Change/Gain Scores. California: Indiana University.

Jackson, D.W. (2011). Standard Barcodes Beware-Smartphone Users May Prefer QR Codes. Law Library Journal, 103 (1), 153.

Larson-Hall, J. (2010). A Guide to Doing Statistics in Second Language Research using SPSS. New York: Routledge.

Lukman \& Ishartiwi. (2014). Pengembangan Bahan Ajar dengan
Model Mind Map untuk Pembelajaran Ilmu Pengetahuan Sosial SMP. Jurnal Inovasi Teknologi Pendidikan (volume 1 nomor 2 edisi tahun 2014). Hlm 112.

Ridwan, F.Z., Santoso, H., \& Agung W.P. (2010). Mengamankan Single Identity Number (SIN) Menggunkan QR Code dan Sidik Jari. Internetworking Indonesia Journal, 2 (2), 17-20.

Rodgers, D.L. \& Withrow-Thorton, B.J. (2005). The Effect of Instructional Media on Learner Motivation. International Journal of Instructional Media. (4), 333.

Sugiyono. (2014). Metode Penelitian Kuantitatif, Kualitatif dan RnD. Bandung: Alfabeta.

Yudhanto, Y. (2011). Sejarah Teknologi Barcode. Diakses pada tanggal 4 Maret 2017, dari http://www.ilmukomputer.org/wpcontent/uploads/2011/03/sejarahbarcode-yudha.pdf. 